\title{
The ex vitro rooting of blueberry (Vaccinium corymbosum L.) microcuttings
}

\author{
Andrzej Pacholczak*, Karolina Nowakowska \\ Department of Ornamental Plants \\ Faculty of Horticulture, Biotechnology and Landscape Architecture \\ Warsaw University of Life Sciences \\ Nowoursynowska 166, 02-787 Warsaw, Poland
}

\begin{abstract}
A growing demand for blueberry fruit has necessitated the development of an efficient propagation method of this species that would provide large quantities of planting material. The aim of this study was to evaluate the effects of auxin indole-3-butyric acid (IBA $50 \mathrm{mg} \mathrm{dm}^{-3}$ ), the commercial rooting powder Rhizopon containing $1 \%$ IBA, and salicylic acid $\left(50 \mathrm{mg} \mathrm{dm}^{-3}\right)$ on the in vivo rooting of microcuttings of Vaccinium corymbosum 'Bluecrop' and 'Duke'. The contents of chlorophyll $a+b$, soluble proteins, free amino acids, as well as total soluble and reducing sugars were determined in rooted cuttings. All of the treatments increased the degree and percentage of rooting in the cuttings of both cultivars. While improving rhizogenesis in blueberry, salicylic acid did not perform as a cofactor of the auxin IBA. Foliar applications of IBA or salicylic acid (SA) increased the contents of soluble proteins, free amino acids and sugars, but no effects on chlorophyll levels were observed.
\end{abstract}

Key words: micropropagation, rhizogenesis, ericaceous plants, organic compounds

\section{INTRODUCTION}

The blueberry (Vaccinium corymbosum L.) cultivars available on the market were bred in the USA so the species is also known as the American blueberry. Because of the fruit's dietetic and health benefits (Strik 2006), the plant is gaining popularity all over the world and its production is spreading in different countries. In Poland, blueberry is still considered a luxury product because of its high price due to a high labour and financial input in fruit production. However, demand for fruits on the Polish market is constantly growing and according to information from the Main Statistical Office, the blueberry yields in 2014 increased by nearly $10 \%$ relative to the mean production in 2006-2010. Also, the plantation surface keeps increasing, having reached 3000 ha in 2012. This growing demand for fruit necessitates a need to develop the most efficient propagation method for this species, as now the rooted cuttings of blueberry have to be ordered two years in advance. Commercially, blueberry is propagated by semi-lignified or soft wood stem cuttings as well as in vitro. Micropropagation is the most efficient method of mass production, and also allows for obtaining healthy and uniform plant material. The supporters of this method (Gomez and Smagula 1987, Read et al. 1989) are convinced that blueberry bushes obtained in vitro are more vigorous (El-Shiekh et al. 1996).

Studies like the ones described in this paper may result in a modification of the method of blueberry propagation that is cheaper than traditional

\footnotetext{
*Corresponding author.

Tel.: +48 2259322 68; fax: +48 2259322 68;

e-mail: andrzej_pacholczak@sggw.pl (A. Pacholczak).
} 
micropropagation, where rooting occurs in vitro, therefore allowing lower production costs and lower prices of cuttings on the market.

The aim of this work was to evaluate the effects of the auxin IBA $\left(50 \mathrm{mg} \mathrm{dm}^{-3}\right)$, the commercial rooting powder Rhizopon containing 1\% IBA and salicylic acid, the auxin cofactor $\left(50 \mathrm{mg} \mathrm{dm}^{-3}\right)$ on the in vivo rooting of microcuttings of Vaccinium corymbosum 'Bluecrop' and 'Duke'. To get an insight into the action of the auxin and its cofactor, the contents of chlorophyll $a+b$, soluble proteins, free amino acids, as well as total soluble and reducing sugars were also determined in the rooted cuttings.

\section{MATERIAL AND METHODS}

Microcuttings of two blueberry cultivars (Vaccinium corymbosum L. 'Bluecrop' and 'Duke') were rooted in the nursery of Jan Ciepłucha in Konstantynów Łódzki. Both cultivars are widely planted in commercial plantations in Poland. The experiment began on 14 February 2015. The experimental material consisted of the tip of onenodal cuttings taken from the plantlets cultured in vitro which were multiplicated on Woody Plant Medium enriched with $20 \mathrm{~g} \mathrm{dm}^{-3}$ sucrose and $5 \mathrm{mg} \mathrm{dm}^{-3} 2 \mathrm{iP}, \mathrm{pH} 5.2$. They were rooted in plastic trays filled with a mixture of peat and perlite $(2: 1$ $\mathrm{v} / \mathrm{v}), \mathrm{pH} 5.0$, and placed in a phytotron under $25^{\circ} \mathrm{C}$ and $16 \mathrm{~h}$ days, with an irradiance of $50 \mu \mathrm{mol} \mathrm{m}^{-2} \mathrm{~s}^{-1}$. There were five treatments, each in triplicate, each containing 100 microcuttings. In one treatment the cuttings were treated with the rooting powder Rhizopon AA (1\% IBA) applied to the cuttings' bases while the four other treatments included foliar applications. They included: IBA water solution (50 $\mathrm{mg} \mathrm{dm}^{-3}$ ), salicylic acid (SA $50 \mathrm{mg} \mathrm{dm}^{-3}$ ), a mixture of both solutions (v/v 1:1) and water as the control treatment.

The cuttings were sprayed until the entire leaf surface was covered with a solution. This treatment was performed once, immediately after placing cuttings in boxes filled with the rooting medium. A hand pressure sprayer of $1 \mathrm{dm}^{3}$ volume was used.

Percentages of rooted cuttings and the degree of rooting were determined three weeks after the start of the experiment. The degree of rooting was evaluated on a five-point scale rating the development of the root ball (Tab. 1). The percentage of rooted cuttings was also calculated; only cuttings with root systems within the scale range of 2-5 were regarded as rooted and counted.

For biochemical analyses, leaves from 20 cuttings per treatment from treated and untreated cuttings were collected at the end of the experiment (three weeks after the beginning of the experiment). They were finely chopped, mixed and $0.25 \mathrm{~g}$ samples were used for the measurements. Triplicate extracts were prepared for each analysis and three measurements were done for each extract, producing nine readings for each data point.

Total chlorophyll content (chlorophyll $a+b$ ) was analysed according to Lichtenthaler and Wellburn (1983). Total soluble sugars were determined according to Dubois et al. (1956), while the reducing sugars were determined using the colorimetric Somogyi method as modified by Nelson (1944). Soluble proteins were determined according to the Bradford method (1976) and free amino acids according to Rosen (1957).

\section{Statistical analysis}

To compare the means, percentages of rooted cuttings were transformed according to Bliss (Wójcik and Laudański 1989), while the degree of rooting by root transformation: $y=x^{2}+(x+1)^{2}$. All of the data were subjected to one-factorial ANOVA followed by Duncan's test at $p=0.05$. The Statgraphics 4.1. program was used.

\section{RESULTS AND DISCUSSION}

\section{Rooting of microcuttings}

The statistical analysis showed significant effects of the treatments on rooting degree and the percentage of rooted cuttings in both blueberry cultivars (Figs

Table 1. Evaluation scale of root development

\begin{tabular}{ll}
\hline Characteristic of the degree of rooting & Score \\
\hline Cutting without visible roots & 1 \\
A few (1-3) short roots & 2 \\
$4-5$ roots, some of them branched, no root ball formed & 3 \\
Medium sized root system composed of 6-10 branched roots forming a root ball & 4 \\
Well developed, branched root system forming a root ball (over 10 roots) & 5 \\
\hline
\end{tabular}




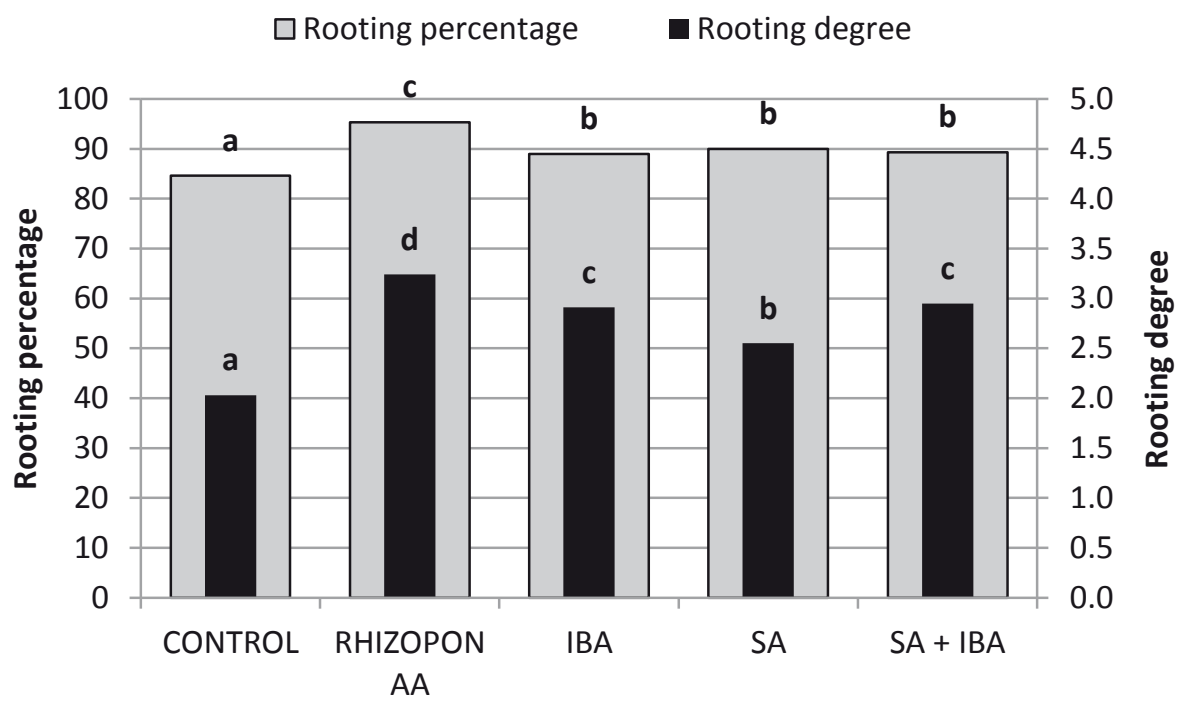

Figure 1. The effect of treatments on rooting degree and percentage of rooted cuttings in 'Bluecrop' blueberry

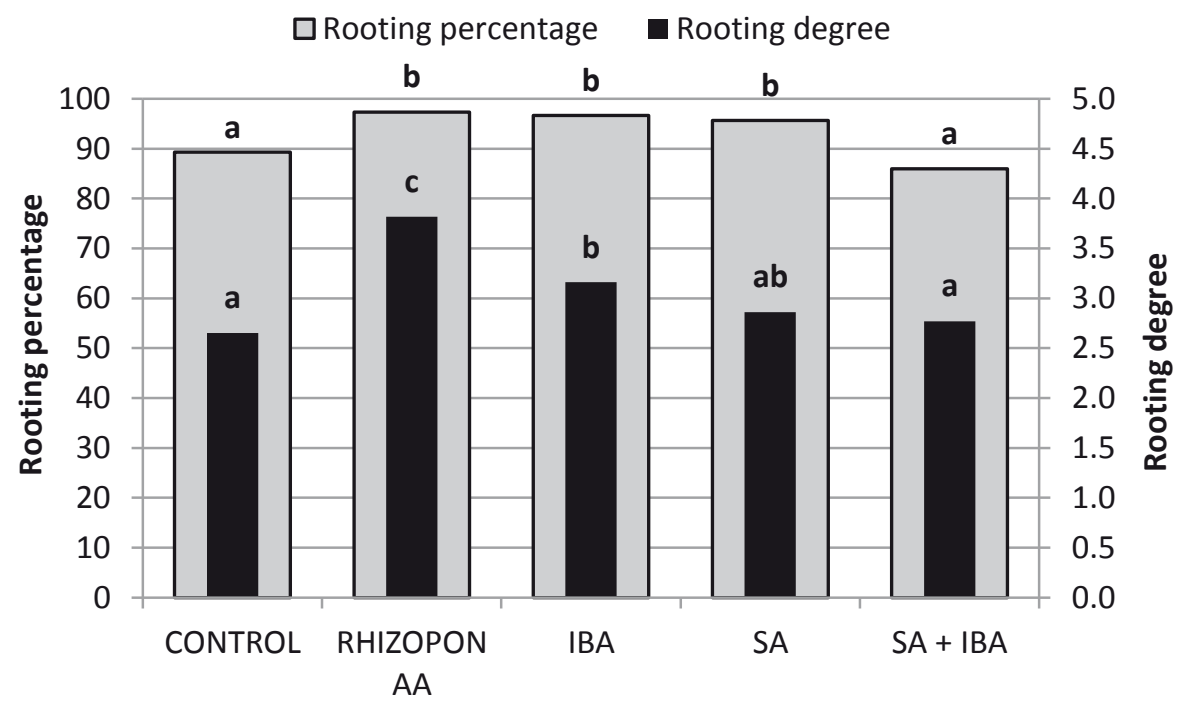

Figure 2. The effect of treatments on rooting degree and percentage of rooted cuttings in 'Duke' blueberry

1 and 2). The lowest rooting degree, 2.0, was found in the control, in untreated cuttings of 'Bluecrop' (Fig. 1). In 'Duke' not only the control cuttings but also those treated with salicylic acid, alone or in combination with IBA, were poorly rooted, with a score of 2.6 in the five-point evaluation scale (Fig. 2). In both cultivars the application of Rhizopon AA gave the best results - the root balls attained the value of 3.3 and 3.8 for 'Bluecrop' and 'Duke', respectively. The water IBA solution also improved the degree and percentage of rooting relative to the respective controls (Figs 1 and 2), while SA had no effect on the rooting degree. It has been widely recognised that changes in auxin concentrations within plants affect various aspects of plant growth and functioning (Wróblewska
2013) and using auxins to stimulate rhizogenesis is commonly appreciated (Khan et al. 2009). Here we show that the foliar application of the water IBA solution improved rhizogenesis in blueberry microcuttings rooted ex vitro.

The highest rooting percentage in 'Bluecrop' (10\% higher than in the control) was obtained after the application of the rooting powder Rhizopon AA. The high efficiency of this preparation has been confirmed by Pacholczak et al. $(2012,2013)$ on stem cuttings in ninebark (Physocarpus opulifolius 'Dart's Gold' and 'Red Baron') and dogwood (Cornus alba 'Aurea' and 'Elegantissima'). In 'Duke' the effects of Rhizopon AA and the water solution of IBA and SA were comparable (Fig. 2). Rooting is affected not only by auxins but also by 
cofactors of rhizogenesis such as vitamins (like vitamin $\mathrm{B}$ - riboflavin, vitamin $\mathrm{C}$ - ascorbic acid), polyamides, amino acids, microelements such as manganese, zinc, boron or iron and phenolic compounds, including salicylic acid or rutin. The above compounds or elements rarely affect rhizogenesis alone and they usually act additively or synergistically with auxins (Jankiewicz 1997). We tested salicylic acid as an auxin cofactor in this study. Reports on the positive effects of salicylic acid on shoot and root mass increases can be found in the literature (Matysiak and Adamczewski 2009). Yamashita et al. (2006) proved that rooting cofactors used together with the auxin IAA increased rooting degree in Mangifera indica. The same was proved by Szydło et al. (2007) in Hedera helix and Ilex $\times$ meserveae. The above observations were not confirmed in our work on blueberry. SA, when applied alone, tended to improve rhizogenesis relative to the respective controls and was almost comparable to IBA; however, in the case of the joint application of SA and IBA (v/v 1:1), it did not improve the efficiency of the IBA solution in 'Bluecrop' and significantly decreased it in 'Duke'.

\section{Biochemical parameters}

To get some insight into the mechanism of the auxin IBA and salicylic acid action on metabolism during rhizogenesis, several organic compounds were determined in rooted blueberry microcuttings.

The treatments significantly affected the contents of total soluble and reducing sugars, free amino acids and soluble proteins while the levels of chlorophyll $a+b$ were unaffected (Tab. 2). An increase in chlorophyll was reported by Mshelmbula et al. (2015) in sesame after IBA application, and Nowak and Wróbel (2010) observed a similar increase in soybean after treatment with $10^{-5} \mathrm{~mol}$ $\mathrm{dm}^{-3}$ salicylic acid while Hashmi et al. (2012) observed the same in Foeniculum vulgare Mill. A contrasting plant response to SA application was reported by Poór et al. (2011) in tomato.

Denaxa et al. (2012) proved that the foliar application of IBA increased sugar content in olive plants. A high sugar level is evidence of efficient photosynthesis and is beneficial for plants as a source of energy for rhizogenesis (Sivaci 2006). In blueberry, all the treatments increased the reducing sugar content while the levels of total soluble sugars were comparable. The highest increases in reducing sugars were observed in 'Bluecrop' after the application of Rhizopon AA, IBA and SA, by $45 \%, 45 \%$ and $32 \%$, respectively, as compared to the control. The joint application of IBA and SA resulted in a smaller increase of $19 \%$ relative to the control.

In 'Duke' the reducing sugars increased due to treatments with Rhizopon AA and SA, by $17 \%$ and $34 \%$ relative to the control. Similarly, Ghasemzadeh and Jaafar (2012) reported an increase in carbohydrates after the treatment of ginger plants with salicylic acid.

Free amino acids are components of proteins and a material for various structures as well as precursors of different metabolites. Together with a high soluble protein level, their high content may indicate the juvenile phase of the cutting (Al Asbahi and Al Maqtari 2012). The lowest contents of free amino acids were determined in the control cuttings in both blueberry cultivars (Tab. 2). In

Table 2. The effect of treatments on the contents of select organic compounds in the cuttings of two blueberry cultivars (values are expressed per $g$ of fresh weight)

\begin{tabular}{lcccccc}
\hline \multirow{2}{*}{ Treatment } & Cultivar & $\begin{array}{c}\text { Chlorophyll } \\
(\mathrm{mg})\end{array}$ & $\begin{array}{c}\text { Reducing } \\
\text { sugars } \\
(\mathrm{mg})\end{array}$ & $\begin{array}{c}\text { Total sugar } \\
(\mathrm{mg})\end{array}$ & $\begin{array}{c}\text { Free amino acids } \\
(\mu \mathrm{mol})\end{array}$ & $\begin{array}{c}\text { Soluble proteins } \\
(\mathrm{mg})\end{array}$ \\
\hline \multirow{2}{*}{ CONTROL } & 'Bluecrop' & $2.08 \mathrm{a} *$ & $8.02 \mathrm{a}$ & $10.06 \mathrm{a}$ & $24.09 \mathrm{a}$ & $1.51 \mathrm{a}$ \\
& 'Duke' & $1.92 \mathrm{a} *$ & $8.70 \mathrm{a}$ & $10.16 \mathrm{a}$ & $18.32 \mathrm{a}$ & $1.26 \mathrm{a}$ \\
\hline \multirow{2}{*}{ RHIZOPON AA } & 'Bluecrop' & $2.34 \mathrm{a}$ & $11.64 \mathrm{c}$ & $11.92 \mathrm{~b}$ & $27.76 \mathrm{~b}$ & $1.72 \mathrm{ab}$ \\
& 'Duke' & $1.96 \mathrm{a}$ & $10.18 \mathrm{~b}$ & $11.67 \mathrm{~b}$ & $21.11 \mathrm{a}$ & $1.61 \mathrm{~b}$ \\
\hline \multirow{2}{*}{ IBA } & 'Bluecrop' & $2.09 \mathrm{a}$ & $11.61 \mathrm{c}$ & $12.28 \mathrm{~b}$ & $30.24 \mathrm{c}$ & $2.43 \mathrm{c}$ \\
& 'Duke' & $1.86 \mathrm{a}$ & $8.82 \mathrm{a}$ & $10.45 \mathrm{a}$ & $39.05 \mathrm{c}$ & $1.55 \mathrm{~b}$ \\
\hline \multirow{2}{*}{ SA } & 'Bluecrop' & $2.33 \mathrm{a}$ & $10.58 \mathrm{bc}$ & $11.83 \mathrm{~b}$ & $29.02 \mathrm{c}$ & $2.48 \mathrm{c}$ \\
& 'Duke' & $1.93 \mathrm{a}$ & $11.68 \mathrm{c}$ & $10.71 \mathrm{ab}$ & $30.25 \mathrm{~b}$ & $1.61 \mathrm{~b}$ \\
\hline \multirow{2}{*}{ SA+ IBA } & 'Bluecrop' & $2.19 \mathrm{a}$ & $9.60 \mathrm{~b}$ & $11.36 \mathrm{ab}$ & $28.05 \mathrm{~b}$ & $1.98 \mathrm{~b}$ \\
& 'Duke' & $1.80 \mathrm{a}$ & $10.01 \mathrm{~b}$ & $11.52 \mathrm{~b}$ & $27.89 \mathrm{~b}$ & $1.28 \mathrm{a}$ \\
\hline
\end{tabular}

*Means in a column followed by the same letter do not differ significantly at $\mathrm{p}=0.05$ 
'Duke', the cuttings treated with the commercial rooting powder also had a low amino acid content. The highest increase in the level of these compounds occurred due to IBA application: by $25 \%$ and $113 \%$ in 'Bluecrop' and 'Duke', respectively, as compared to the controls. Somewhat lower amounts were found in cuttings treated with SA or SA + IBA, where the increase relative to the control was $20 \%$ and $16 \%$ in 'Bluecrop' and $65 \%$ and $52 \%$ in 'Duke', respectively. Ahkami et al. (2013) also observed a $30-40 \%$ increase in free amino acid contents in petunia cuttings treated with IBA. According to Lessufleur et al. (2007), the high levels of free amino acids in plants positively affect the vitality of plant cells and their proper functioning.

The lowest contents of soluble proteins were found in the control treatments of both cultivars as well as in 'Duke' after the joint application of IBA and SA. Other treatments increased the protein levels. As compared to the control, the foliar application of the water solutions of IBA or SA increased the protein content in 'Bluecrop' by $61 \%$ and $64 \%$, respectively, and by $23 \%$ and $27 \%$ in 'Duke'. The presence of proteins in cuttings is important for rhizogenesis because ABP proteins (Actin-Binding Protein) are auxin receptors. Davies (2010) proved that the application of rooting stimulators increased the contents of soluble proteins in potato and tobacco. According to Fahad and Bano (2012), the soluble proteins increased in corn due to a treatment with $10^{-5} \mathrm{~mol} \mathrm{dm}^{-3} \mathrm{SA}$.

The above presented results may be a base for further research aiming to develop the most efficient propagation methods for blueberry (Vaccinium corymbosum L.). They show that it is possible to shorten the period of in vitro culture by transferring unrooted microcuttings to ex vitro conditions where their acclimatization occurs simultaneously with rooting.

\section{CONCLUSIONS}

1. Treatments with auxin IBA and salicylic acid improved rhizogenesis in blueberry microcuttings rooted ex vitro, increasing the rooting degree and the percentage of rooted cuttings.

2. IBA and SA increased the contents of reducing and total soluble sugars, free amino acids and soluble proteins in rooted blueberry microcuttings, but had no effect on the chlorophyll level.
3. While improving rhizogenesis in blueberry, salicylic acid did not perform as a cofactor of the auxin IBA.

\section{FUNDING}

This research was supported by the State Committee for Scientific Research (Poland) as a part of the project: The intensification of propagation of ornamental shrubs by using biostimulants $(\mathrm{NN}$ 310725140).

\section{AUTHOR CONTRIBUTIONS}

A.P. contributed to the entire experimental process, biochemical and data analysis, interpretation, literature research and writing. K.N. was involved in the determination of biochemical compounds.

\section{CONFLICT OF INTEREST}

The authors declare no conflict of interest.

\section{REFERENCES}

Ahkami A.H., Melzer M., Ghaffari M.R., Pollmann S., Javid M.G., Shahinnia F., Hajirezaei M.R., Druege U., 2013. Distribution of indole-3-acetic acid in Petunia hybrida shoot tip cuttings and relationship between auxin transport, carbohydrate metabolism and adventitious root formation. Planta 238: 499-517.

Al Asbahi A.A., Al Maqtari M.A., 2012. ABA biosynthesis defective mutants reduce some free amino acids accumulation under drought stress in tomato leaves in comparison with Arabidopsis plants tissues. J. Stres. Physiol. Biochem. 8: 179-192.

BRADFORD M.M., 1976. A rapid and sensitive method for the quantification of microgram quantities of protein utilizing the principle of protein dye binding. Anal. Biochem. 72: 248-254.

DAvies P.J., 2010. Plant Hormones. Biosynthesis, Signal Transduction, Action! Revised 3th Edition. Springer, New York.

Denaxa N.K., Vemmos S.N., Roussos P.A., 2012. The role of endogenous carbohydrates and seasonal variation on rooting ability of cuttings of an easy and a hard to root olive cultivars. Sci. Hortic. 143: 19-28.

Dubois M., Filles K.A., Hamilton J.K., Rebers P.A., Sмith F., 1956. Colorimetric method for determination of sugars and related substances. Anal. Chem. 28: 350-356.

El-Shiekh A., Wildung D.K., Luby J.J., SArgent K.L., READ P.E., 1996. Long-term effects of propagation by tissue culture or softwood single-node cuttings on growth habit, yield, and berry weight of 'Northblue' blueberry. J. Amer. Soc. Hort. Sci. 121(2): 339-342.

FAHAD S., BANO A., 2012. Effect of salicylic acid on physiological and biochemical characterization of 
maize grown in saline area. Pakistan J. Bot. 44(4): 1433-1438.

GHasemzadeh A., JAAfar H.Z.F., 2012. Effect of salicylic acid application on biochemical changes in ginger (Zingiber officinale Roscoe). J. Med. Plants Res 6(5): 790-795.

Gomez T., Smagula J., 1987. Filling bare spots in blueberry fields. Fact Sheet 221, University of Maine: 1-6.

Hashmi N., Khan M.M.A., Idrees M.M., Aftab T., 2012. Exogenous salicylic acid stimulates physiological and biochemical changes to improve growth, yield and active constituents of fennel essential oil. J. Plant Growth Reg. 68(2): 281-291.

JANKIEWICZ L.S., 1997. Regulatory wzrostu i rozwoju roślin. [Regulators of Plant Growth and Development]. PWN, Warszawa: 108-123.

Khan W., Rayirath U.P., Subramanian S., Jithesh M.N., Rayorath P., Hodges D.M., 2009. Seaweed extracts as biostimulants of plant growth and development. J. Plant Growth Reg. 28: 386-399.

Lessufleur F., Paynel F., Bataillé M-P., Le Deunff E., Cliquet J-B., 2007. Root amino acid exudation: measurement of high efflux rates of glycine and serine from six different plant species. Plant and Soil 294: 235-246.

Lichtenthaler H.K., Wellburn A.R., 1983. Determinations of total carotenoids and chlorophylls $\mathrm{a}$ and $\mathrm{b}$ leaf extracts in different solvents. Biochem. Soc. Trans. 603: 591-592.

Matysiak K., Adamczewski K., 2009. Regulatory wzrostu i rozwoju roślin - kierunki badań w Polsce i na świecie [Regulators of plant growth and development - research directions in Poland and in the world]. Postępy w Ochronie Roślin 49(4): 18101816.

Mshelmbula B.A., Окоовон G., Mensah J.K.,IkhajiagBe B., Zakariya R., 2015. The effects of indole-3acetic acid (IAA) on the growth and yield of sesame (Sesamum indicum L.) under drought conditions. Int. J. Sci. Know. 4(1): 60-65.

Nelson N., 1944. A photometric adaption of the Somogyi method for the determination of glucose. J. Biol. Chem. 153: 375-380.

NowAK A., WróBEL J., 2010. Wpływ egzogennych regulatorów wzrostu na zawartość barwników asymilacyjnych w liściach trzech odmian soi zwyczajnej (Glycine max L. Merr). [The influence of exogenous growth regulators on the content of assimilation pigments in the leaves of three cultivars of soybean (Glycine max L. Merr)]. Rośliny OleisteOilseed Crops XXXI: 351-359.

Pacholczak A., Szydeo W., Jacygrad E., Federowicz M., 2012. Effect of auxins and the biostimulator AlgaminoPlant on rhizogenesis in stem cuttings of two dogwood cultivars (Cornus alba 'Aurea' and 'Elegantissima'). Acta Sci. Pol. Hort. Cult. 11(2): 93103.

Pacholczak A., Szydeo W., Petelewicz P., Szulczyk K., 2013. The effect of AlgaminoPlant on rhizogenesis in stem cuttings of Physocarpus opulifolius 'Dart's Gold' and 'Red Baron'. Acta Sci. Pol. Hort. Cult. 12(3): 105-116.

Poór P., Gémes K., Horváth F., Szepesi A., Simon M.L., TARi I., 2011. Salicylic acid treatment via the rooting medium interferes with stomatal response, $\mathrm{CO}_{2}$ fixation rate and carbohydrate metabolism in tomato, and decreases harmful effects of subsequent salt stress. Plant Biol. 13(1): 105-114.

Read P.E., Wildung D.K., Hartley C.A., Sandahal J.G., 1989. Field performance of in vitro propagated 'Northblue' blueberries. Acta Hort. 241: 191-194.

Rosen H., 1957. A modified ninhydrin colometric analysis for amino acids. Arch. Biochem. Biophys. 67: $10-15$.

Sivaci A., 2006. Seasonal changes of total carbohydrate contents in three varieties of apple (Malus sylvestris Miller) stem cuttings. Sci. Hort. 9: 234-237.

STRIK B., 2006. Blueberry production and research trends in North America. Acta Hort. 715: 173-184.

SzydŁo W., PACholczaK A., ŁukAszewsKa A., 2007. Rooting of stem cuttings of Hedera helix 'Arborescens' as affected by zinc treatment. Ann. Warsaw Univ. Life Sci., Horticult. Landsc. Architect. 28: 79-86.

Wóscik A.R., LAUdAŃSKI Z., 1989. Planowanie i wnioskowanie statystyczne w doświadczalnictwie. [Statistical Planning and Concluding in Experimental Works]. PWN, Warszawa: 130.

WRÓBLEWSKA K., 2013. The influence of benzyladenine and naphthalene-1-acetic on rooting and growth of Fuchsia hybrida cuttings. Acta Sci. Pol. Hort. Cult. 12(1): 101-113.

Yamashita K., Okamura S., Honsho C., Tetsumura T., 2006. Zinc treatment in combination with auxin enhances rooting of cuttings in Taiwan Native Strain of mango (Mangifera indica L.). Nettai Nogyo 50(2): 76-81.

Received August 26, 2015; accepted November 11, 2015 